\title{
Analisis Dampak Media Sosial Terhadap Penjualan Perumahan: Studi Empiris Penggunaan Iklan Facebook dan Instagram
}

\author{
Rully Armanto $^{1)}$ dan Muji Gunarto ${ }^{2 *}$ \\ ${ }^{1)}$ Fakultas Ekonomi, Universitas Taman Siswa \\ ${ }^{2)}$ Fakultas Ekonomi dan Bisnis, Universitas Bina Darma \\ ${ }^{*}$ Email: mgunarto@binadarma.ac.id
}

\begin{abstract}
The development of digital technology is growing rapidly, as well as digital-based marketing activities. Because advertising marketing is the most important part of marketing, of course there are also many kinds of advertising media. In this study, researchers examined Facebook and Instagram social media ads, this study aims to determine how widespread or influence Facebook and Instagram social media ads have on home sales in Palembang. The population in this study is the people of Palembang City who live in Palembang City Housing. The results of this study indicate that both Facebook and Instagram social media ads have a positive effect on sales, but when compared with Facebook social media ads. Instagram has a significant influence.
\end{abstract}

Keywords: social media advertising, Facebook, Instagram, Sales

\section{Pendahuluan}

Perkembangan Teknologi digital telah mengubah cara manusia dalam melakukan berkomunikasi, tindakan, dan melakukan mengambil keputusan. Media Sosial menjadi salah satu trend tersendiri dalam kehidupan masyarakat khususnya di Indonesia, seakan-akan hal tersebut menjadi kegiatan rutin yang harus dilakukan setiap hari, Salah satu lembaga survey Wearesocial merilis data terbaru pada bulan Januari 2020 pengguna Sosial Media di Indonesia mencapai 130 Juta jiwa dengan Penetrasi mencapai 49\%. Banyaknya berbagai macam iklan di media sosial yang bermunculan dengan cara tampilan yang dikemas sedemikian rupa membuat konsumen merasa tertarik untuk melakukan pembelian, serta kemudahan untuk mendapatkan informasi tentang produk yang mereka cari karena konsumen bisa langsung berinteraksi dengan penjual secara langsung sehingga hubungan terus antara kedua belah pihak dapat terjalin.

Salah satu media sosial yang paling sering digunakan sebagai media iklan adalah media sosial seperti Facebook dan Instagram hal ini dikarenakan Facebook dan Instagram ini sangat memberikan kemudahan bagi semua orang untuk memasarkan dan mempromosikan produknya dengan biaya yang cukup minim hingga gratis karena pengguna tidak perlu mengeluarkan biaya pemasangan iklan secara komersil pada iklan media cetak ataupun media elektronik, Media iklan ini sangatlah berguna bagi penjualan suatu produk. Kota Palembang 
sebagai ibukota Provinsi Sumatera Selatan Palembang merupakan sebuah kota Metropolitan dimana di dalamnya terdapat beragam aktivitas kehidupan masyarakat, Perkembangan kota Palembang begitu sangat cepat bisa dilihat dalam 5 tahun terakhir maraknya pertumbuhan infrastruktur, saran dan prasarana kota, dan roda perekonomian yang terus menggeliat.

Penjualan menggunakan media sosial cukuplah sangat praktis dalam penggunaanya dan memberikan dampak positif dalam penjualanya, bagi konsumen juga dapat merasa lebih nyaman dikarena mendapatkan informasi yang secara lengkap dan up date, tidak ada pemisah jarak untuk diakses dan bermanfaat untuk bertukar informasi antara calon pembeli dan pemasar.

Tabel 1

Data Perumahan Yang Menjual Dengan Menggunakan Iklan Media Sosial Facebook Dan Instagram

\begin{tabular}{ll}
\hline \multicolumn{1}{c}{ Nama Perumahan } & \multicolumn{1}{c}{ Wilayah } \\
\hline Arizona Greenland & kecamatan ilir barat I, Palembang \\
Arizona Taman Abadi & Kecamatan Kalidoni, Palembang \\
Cahaya Biru Residence & Kecamatan Talang Kelapa, Palembang \\
\hline
\end{tabular}

Data tabel diatas terdapat 2 perusahaan, nama perumahan dan wilayah perumahan. perumahan tersebut menggunakan iklan di media sosial Facebook dan Instagram.

Tabel 2

Permasalahan Yang Sering Dihadapi Perusahaan Menggunakan Iklan Di Media Sosial

\begin{tabular}{ll}
\hline No & \multicolumn{1}{c}{ Permasalahan } \\
\hline 1 & $\begin{array}{l}\text { Persaingan dengen kompetitor meliputi desain, } \\
\text { gambar, dan kualitas yang di tampilkan. }\end{array}$ \\
2 & \begin{tabular}{l} 
Kepercayan konsumen. \\
\hline
\end{tabular}
\end{tabular}

Dari data tabel 2 terdapat permasalahan yang sering dialami bagi pemasaran dalam melakukan penjualannya, Tabel permasalahan tersebut didapat dengan cara melakukan wawancara kepada pihak yang terkait dalam melakukan penjulan perumahan.

Tetapi dalam memasarkan perumahan melalui media sosial sering kali konsumen menemukan ketidak sesuai dengan ekspetasi konsumen dikarenakan foto dan sertifikasi produk atau bangunan yang di tawarkan oleh media iklan Facabook dan Instagram tidak sesuai dengan realitanya sehingga sebagian konsumen merasakan kecewa saat melakukan survei langsung ke tempat lokasi perumahan tersebut. Dalam memenuhi kepuasan konsumen, perusahaan memang di tuntut kejelihanya untuk mengetahui pergeseran kebutuhan dan keinginan konsumen yang hampir setiap saat berubah. Pembeli akan bergerak setelah membentuk persepsi terhadap nilai penawaran dibandingkan dengan harapannya, Kepuasan konsumen adalah tingkat perasaan seseorang setelah membandingkan (kinerja atau hasil) yang dirasakan dibandingkan dengan harapannya 


\section{Kajian Literatur}

\subsection{Media Iklan}

Menurut kamus besar bahasa Indonesia (KBBI) iklan adalah berita atau pesan untuk mendorong, membujuk khalayak ramai agar tertarik pada barang dan jasa yang ditawarkan, atau pemberitahuan kepada khalayak mengenai barang atau jasa yang dijual, dipasang di dalam media massa (seperti surat kabar dan majalah) atau di tempat umum.

iklan dapat disimpulkan bahwa periklanan sebagai salah satu jenis komunikasi komersial dengan membayar ruangan atau waktu untuk menyiarkan informasi tentang produk atau jasa melalui media massa (Murad \& Rafsanjani, 2016). iklan adalah yakni bauran pemasaran yang merupakan strategi campuran berbagai kegiatan pemasaran yang dijadikan kombinasi yang maksimal sehingga mendatangkan hasil yang paling memuaskan (Ayu Pradnya Indrawati et al., 2017). Iklan merupakan salah satu bentuk promosi yang paling banyak digunakan perusahaan dalam mempromosikan produknya (Adhi Suryo \& Suddin, 2019). Iklan adalah setiap bentuk komunikasi nonpersonal mengenai suatu organisasi, produk, servis, atau ide yang dibayar oleh satu sponsor yang diketahui.(Setiawan Sumana Putra \& Wulandari, 2018)

Sementara manfaat iklan bagi pembangunan masyarakat dan ekonomi antara lain :

1. Iklan memperluas alternatif bagi konsumen.

Dengan adanya iklan, konsumen dapat mengetahui adanya berbagai produk, yang giliranya menimbulkan adanya pilihan.

2. Iklan membantu produsen menimbulkan kepercayaan bagi kosumennya.

Sering dikatakan "tak kenal maka tak sayang", Iklan yang secara gagah tampil di hadapan masyarakat dengan ukuran besar dan logo yang cantik menimbulkan kepercayaan yang tinggi bahwa perusahaan yang membuatnya bahagia dan produknya bermutu. Iklan membuat orang kenal, ingat dan percaya terhadap perusahaan dan produkya.(Murad \& Rafsanjani, 2016). Menurut (Hari Wibisono, 2012) indikator iklan adalah dapat menimbulkan perhatikan, menarik, dapat menimbulkan keinginan, dan menghasilkan suatu tindakan.

\subsection{Media sosial}

Media sosial adalah sebuah media online, dengan para penggunanya bisa dengan mudah berpartisipasi dan menciptakan isi meliputi blog, jejaring sosial wiki, forum, dan dunia virtual. Tujuan media sosial iyalah menawarkan konten komunikasi yang lebih individual, melalui media sosial ini juga berbagai kalangan pemasaran bisa mengetahui kerahasiaan dari konsumen mereka dan melakukan suatu interaksi secara personal dan juga bisa membangun suatu komunikasi yang lebih mendalam.(Puntoadi, 2011). Menurut (Roma Doni, 2017) Fungsi media sosial dapat diketahui melalui sebuah kerangka kerja honeycomb.

Sosial media memiliki beberapa fungsi sebagai berikut :

1. Sosial media adalah media yang didesain untuk memperluas interaksi sosial manusia menggunakan internet dan teknologi web.

2. Sosial media berhasil mentransformasi praktik komunikasi searah media siaran dari satu institusi media ke banyak audience (one to many) menjadi praktik komunikasi dialogis antar banyak audience (many to many).

Sosial media mendukung demokratisasi pengetahuan dan informasi Mentransformasi manusia dari pengguna isi pesan menjadi pembuat pesan itu sendiri. 


\subsection{Facebook}

Facebook adalah sebuah layanan jejaring sosial berkantor Pusat di Menlo Park, California, Amerika Serikat yang diluncurkan pada bulan Febuari 2004. Hingga September 2012, Facebook memiliki lebih dari satu miliar pengguna aktif memiliki lebih dari separuhnya pengguna telepon genggam. Menurut (Zarrella, 2010) situs jejaring sosial Facebook sangat bermanfaat bagi pemasaran karena menyediakan sejumlah layanan untuk berinteraksi dengan pelanggan, misalnya melalui plug-in application, group, dan halam fan. Manfaat Facebook bagi manajemen perusahaan Menurut (Puntoadi, 2011) sebagai berikut :

1. Cara muda promosi penggunaan media sosial merupakan cara murah dalam iklan online. Dengan biaya yang relatif gratis yang digunakan perusahaan, perusahaan dapat melakukan promosi produk mereka ke banyak konsumen.

2. Identifikasi target pasar juga dapat dilakukan dengan muda dengan bergabung ke grubgrub yang mempunyai minat dan kebutuhan yang sama. Facebook juga membantu perusahaan untuk berpromosi dengan memanfaatkan fitur : update, status, upload foto dan vidio, wall, chat atau obrolan yang semuanya termuat di dalam akun Facebook.

Fitur-fitur Facebook dapat digunakan sebagai alat berpromosi menurut (Danis Puntoadi, 2011) sebagai berikut :

1. Conneting (koneksi)

Peran terpening dari jejaring sosial adalah menghubungan (connecting) dua orang atau lebih. Facebook menekankan hubungan antara pemasaran dengan masyarakat luas. Facebook memudahkan konsumen tersebut dengan pemasar.

2. Upload (Status)

Status yang biasa digunakan untuk menuangkan ide atau tulisan apapun untuk berpromosi, dengan cara menuliskan sesuatu yang berhubungan dengan produk atau jasa suatu perusahaan, selain itu update status dapat mencantumkan link yang menuju ke website perusahaan.

3. Upload foto atau vidio

Menu upload foto dan vidio di Facebook dapat digunakan untuk berpromosi, Dengan upload foto atau video produk yang berisi menawarkan pemasaran dapat membeli.

\subsection{Instagram}

Instagram adalah sebuah aplikasi berbagi foto dan vidio yang memungkinkan pengguna mengambil foto, mengambil vidio, menerapkan filter, dan aktivitas jejaring lainnya. Nama Instagram berasal dari kata instan dan telegram. Kata instan yang mendasari penamaan insta dimaksud kan seperti kamera polaroid yang pada masanya lebih dengan sebutan foto instan. Menurut (Ayu Pradnya Indrawati et al., 2017) Instagram memiliki 5 menu utama yang semuanya terletak pada bagian tampilan bawah. Sebagai berikut:

\section{Home page}

Home page adalah halaman utama yang menampilkan (Timeline) foto-foto terbaru dari sesama pengguna yang diikuti, cara melihat foto yaitu hanya dengan menggeser layar dari bawah ke atas sepeti saat scroll mouse di komputer. Kurang dari 30 foto terbaru dimuat saat pengguna di akses aplikasi, Instagram hanya membatasi foto-foto terbaru.

2. Comments

Sebagai layanan jejaring sosial Instagram menyediakan fitur komentar, foto-foto yang ada 
di Instagram dapat komentar di kolom komentar, caranya tekan ikon bertanda kolom komentar di bawah foto, kemudian ditulis kesan-kesan mengenai foto pada kotak yang disediakan setelah itu tekan tombol send.

3. Expore

Explor merupakan tampilan dari foto-foto populer yang paling banyak disukai para pengguna Instagram. Instagram menggunakan algoritma rahasia untuk menentukan foto mana yang mana dimasukkan ke dalam explore feed.

4. Profil

Profil pengguna dapat mengetahui secara detail mengenai informasi pengguna, baik itu dari pengguna maupun sesama pengguna yang lainya. Halaman profil bisa diakses melalui ikon kartu nama di menu utama bagian paling kanan. Fitur ini menampilkan jumlah foto yang telah diupload, jumlah follower dan jumlah following.

5. New feed

New feed merupakan fitur menampilkan notifikasi terhadap berbagai aktifitas yang dilakukan oleh pengguna Instagram new feed memiliki dua jenis tab yaitu following dan news tab following menampilkan aktifitas terbaru pada user yang telah pengguna follow maka pemberitahuan tersebut akan muncul di tab ini.

\subsection{Penjualan}

Penjualan adalah aktifitas atau bisnis dalam menjual produk atau jasa penjualan dapat diartikan sebagai kegiatan jual beli dijalankan oleh kedua belah pihak atau lebih dengan alat pembayaran yang sah. Menurut (Firli Musfar, 2020) menjelaskan arti penjualan adalah suatu peroses pertukaran barang atau jasa antara penjual yang dilakukan manusia untuk menyampaikan barang kebutuhan yang telah dihasilakan kepada mereka yang membutuhkan yang telah ditentukan atas tujuan bersama.

Tujuan penjualan iyalah untuk mendapatkan laba yang dihasilkan dari produsenya dengan cara mengolah dengan baik. Menurut (Musfar, 2020) Tujuan penjualan adalah mencapai volume penjualan, mendapatkan laba tertentu dan menunjang pertumbuh usaha.

Menurut (Musfar, 2020) Terdapat indikator dari volume penjualan adalah sebagai berikut :

1. Mencapai volume penjualan

Volume penjualan iyalah bahwa menujukan jumlah barang yang dijual dalam jaka waktu tertentu. penjualan adalah interaksi antara idividu yang salaing bertemu muka yang ditujukan untuk menciptakan, memperbaiki, atau mempertahankan hubugan perukaran sehingga menguntugkan bagi pihak lain.

2. Mendapatkan Laba

laba merupakan selisih pendapatan dan keuntugan setelah dikurangi beban dan kerugian laba sebagai pengukur aktifitas oprasi dan dihitung berdasarkan akuntansi akural.

3. Menunjang Pertumbuhan Perusahaan

bahwa pertumbuhan perusahaan iyalah kemampuan perusahaan untuk meningkatkan ukuran perusahaan melalui aktiva

\subsection{Penelitian Terdahulu}

Analisis Pemanfaatan Facebook Sebagai Media Promosi Produk Perumahan Syariah di PT.Jannata Land (Tasliman \& Suryawibawa, 2019). Hasil Hasil penelitian Dampak Positif : Facebook memberikan kemudahan untuk mempromosikan produk PT.Jannati Land Yaitu Perumahan syariah kepada target market yang spesifik dengan harga yang relatif murah dan 
jika konten iklan berhasil tayang maka target sasaran akan lebih mudah mendapatkan informasi tentang produk yang ditawarkan serta facebook akan menapilkan repot atau hasil dari kinerja iklan berupa data yang lengkap dan spesifik. Dampak Negatif : Beriklan di Facebook tentunya harus mempunyai kemampuan analisis yang sangat baik, menetapkan goal yang spesifik serta kemampuan targeting. Analisis Efektifitas Iklan Dewarumah Melalui Media Sosial Instagram Menggunakan Metode EPIC Model. Hasil Analisa penelitian pengukuran efektivitas iklan dewarumah melalui jejaring media Instagram menggunakan metode EPIC diketahui dimensi Empathy menghasilkan skor kumulatif rata - rata 4,095 skor menempati nilai Efektif masuk pada rentan skala 3,40 - 4,20. Hal ini menginformasikan bahwa para pencarian rumah menggangap iklan instagram tampil bereda dan mudah di ingat dibadingkan dengan portal penjualan rumah lainya (Septi Haryani, 2019). Pengaruh Periklanan Dan Promosi Penjualan Terhadap Keputusan Pembelian Pada Perumahan Griya Puspan Dari Asri Tanjung Pinang. Hasil yang didapat dari penelitian ini adalah periklan dan promosi penjualan secara parsil dan simuta berpengaruh terhadap keputusan pembelian di perumahan griya puspan dari asri tanjung pinang. Maka dapat disimpulkan bahwa semakin baik periklanan dan promosi penjualan, akan meningkatkan keputusan pembelian pada perumahan gria puspandari Asri tanjung pinang (Indrawati et al., 2017). Efektivitas Iklan Melalui Media Sosial Facebook Dan Instagaram Sebagai Salah Satu Strategi Pemasaran di Krisna Oleh-oleh Khas Bali. Hasil yang didapat dari pegukuran dimensi empathy dari tiga pertanyaan yang diwakilkan menunjukan nilai EPIC sebesar 3,95 menunjukan iklan tersebut mampu memberikan informasi dan pesan kepada konsumen secara efektif, dan mengindikasikan bahwa iklan tersebut disukai dan memiliki daya tarik yang tinggi.

\subsection{Hipotesis Penelitian}

Penelitian Hipotesi merupakan suatu penyataan yang masih belum pasti kebenaranya,maka dapat di uji lagi kebenaranya. Berdasarkan dari uraian diatas, peneliti membuat peryataan yang akan diuji dalam penelitianya sebagai berikut :

$\mathrm{H}_{1}$ : Di duga dampak Media iklan Facebook berdampak secara parsial terhadap hasil penjualan perumahan di Palembang

$\mathrm{H}_{2}$ : Di duga dampak Media iklan Instagram berdampak secara parsial terhadap hasil penjualan perumahan di Palembang

$\mathrm{H}_{3}$ : Di duga media iklan Facebook dan Instagram secara simultan berdampak terhadap hasil penjualan perumahan di Palembang.

\section{Metode Penelitian}

\subsection{Objek Penelitian}

Objek dalam penelitian ini dilakukan di perumahan yang berada di Kota Palembang.

\subsection{Populasi Dan Sampel}

Populasi dalam penelitian ini adalah seluruh masyarakat yang telah tinggal diperumahan kota Palembang yang jumlahnya tidak diketahui dikarenakan keterbatasan sumber informasi. Sempel dalam penelitian ini berjumlah 100 orang

\subsection{Operasional Variabel}

Dalam penelitian ini terdapat 3 variabel yaitu iklan Facebook (X1), iklan instagaram (X2), Variabel dependen dan Penjualan (Y) sebagai variabel independen 


\subsection{Jenis Dan Sumber Data}

Jenis dan sumber data yang digunakan peneliti sebagai berikut :

1. Data Kualitatif

Data kualitatif merupakan data yang merupakan berbentuk lisan atau bukan dalam bentuk angka, penelitian untuk mendapatkan data dengan cara wawancara terhadap pihak yang terkait dalam penelitian.

2. Data Kualitatif

Data kualitatif adalah data yang merupai bentuk angka-angka yang dapat di hitung yang di peroleh dari kuesioner.

\subsection{Sumber Data}

1. Data primer

Data primer adalah data yang berasal dari responden langsung. Data ini di peroleh dari hasil wawancaran langsung dengan pihak-pihak terkait perusahaan

2. Data Sekunder

Data sekunder adalah data yang diperoleh dari secara tidak langsung. Data sekunder dalam penelitian ini dari jurnal, buku, dan internet yang berkaitan dengan penelitian.

\subsection{Metode Pengumpulan Data}

\section{Observasi}

Observasi adalah metode data penelitian dan melihat situasi, kondisi, serta lokasi.

2. Wawancara

Wawancara adalah metode untuk penggumpulan data dengan cara tanya jawab pada pihak yang terkait. dalam penelitian ini peneliti melakukan wawancara dengan pihak-pihak perusahan perumahan di Palembang

3. Studi Pustaka

Studi pustaka adalah metode Untuk mengumpulkan data-data yang berkaitan dengan objek yang di teliti serta yang bersumber dari buku-buku yang berkaitan dengan penelitian ini.

4. Kuesioner

Kuesioner adalah metode pengumpulan data dengan memberikan daftar pertanyaan kepada responden, dan mengharapkan respon atas pertanyaan tersebut. menurut (Sugiyono, 2016) . Dalam penelitian ini penulis membuat kuesioner dengan bentuk pertanyaan.

\subsection{Teknik Analisis Data}

Dalam penelitian ini peneliti menggunakan Analisi stastistik inferensial yaitu regresi linier berganda. Teknik analisis ini sangat umum digunakan sehingga mudah dipahami untuk melakukan teknik analisis Regresi Berganda (Hurriyati dan Gunarto, 2019). Rumus yang digunakan

$$
\mathbf{Y}=\mathbf{a}+\mathbf{b}_{1} \mathbf{X}_{1}+\mathbf{b}_{2} \mathbf{X}_{2}+\mathbf{e}
$$

\section{Hasil dan Pembahasan}

\subsection{Hasil}


Ringkasan model hasil pengolahan diperoleh seperti Tabel 3.

Tabel 3. Ringkasan Model

\begin{tabular}{lc|r|r|r}
\hline Model & R & R Square & Adjusted R Square & Std. Error of the Estimate \\
\hline 1 & $.408^{\mathrm{a}}$ & 0.166 & 0.149 & 0.41986 \\
\hline
\end{tabular}

a. Predictors: (Constant), Instagram, facebook

Tabel 3. menampilkan nilai $\mathrm{R}$ yang merupakan simbol dari nilai koefisien korelasi. Pada nilai diatas nilai korelasi adalah 0,408 Nilai ini dapat diinterpretasikan bahwa hubungan kedua variabel penelitian ada di kategori sedang. Melalui tabel ini juga diperoleh nilai $R$ Square atau koefisien determinasi (KD) yang menunjukkan seberapa bagus model regresi yang dibentuk oleh interaksi variabel bebas dan variabel terikat. Nilai KD yang diperoleh adalah 0,166 yang dapat ditafsirkan bahwa variabel bebas Facebook dan instagram memiliki pengaruh kontribusi sebesar 16,6 \% terhadap penjualan dan 83,4 \% lainnya dipengaruhi oleh faktorfaktor lain diluar variabel bebas. Hasil pengujian secara simultan terlihat pada Tabel 4.

Tabel 4. Hasil pengujian ANOVA

\begin{tabular}{llr|r|r|r|r} 
Model & & Sum of Squares & df & Mean Square & F & Sig. \\
\hline 1 & Regression & 3.416 & 2 & 1.708 & 9.688 & $.000^{\mathrm{b}}$ \\
\cline { 2 - 8 } & Residual & 17.099 & 97 & 0.176 & & \\
\cline { 2 - 8 } & Total & 20.515 & 99 & & & \\
\hline
\end{tabular}

a. Dependent Variable: Penjualan

b. Predictors: (Constant), Instagram, facebook

Berdasarkan hasil pengujian pada Tabel 4 dapat dilihat bahwa variabel terikat memiliki nilai koefisien regresi sebesar 0,16 dan nilai $F$ hitung sebesar 9,688 Nilai $F$ tabel dengan $\mathrm{N}=100$ adalah sebesar 2,70. Dengan demikian nilai $F$ hitung $>$ dari $F$ tabel atau 9,688 $>2,70$. Sementara tingkat signifikansi lebih kecil dari tingkat signifikansi yang ditetapkan yaitu $0.000<0,05$. Hal ini menunjukkan bahwa (Instagram, facebook) berpengaruh secara bersama-sama dan signifikan terhadap variabel dependen (Penjualan)

Tabel diatas digunakan untuk menentukan taraf signifikansi atau linieritas dari regresi. Kriterianya dapat ditentukan berdasarkan uji $\mathrm{F}$ atau uji nilai Signifikansi (Sig.). Cara yang paling mudah dengan uji Sig. dengan ketentuan, jika Nilai Sig. $<0.05$, maka model regresi adalah linier, dan juga berlaku sebaliknya. Berdasarkan tabel ketiga, diperoleh nilai Sig. $=$ 0,000 yang berarti $<$ kriteria signifikan $(0,05)$, dengan demikian model persamaan regresi berdasarkan data penelitian adalah signifikan artinya, model regresi linier memenuhi kriteria linieritas. Hasil pengujian secara parsial terlihat pada Tabel 5.

Tabel 5. Hasil Pengujian Parsial

\begin{tabular}{|c|c|c|c|c|c|c|}
\hline \multirow[b]{2}{*}{ Model } & & \multicolumn{2}{|c|}{$\begin{array}{c}\text { Unstandardized } \\
\text { Coefficients }\end{array}$} & \multirow{2}{*}{$\begin{array}{c}\text { Standardized } \\
\text { Coefficients } \\
\text { Beta } \\
\end{array}$} & \multirow{2}{*}{-} & \multirow[b]{2}{*}{ Sig. } \\
\hline & & B & Std. Error & & & \\
\hline \multirow[t]{3}{*}{1} & (Constant) & 2.309 & 0.543 & & 4.256 & 0.000 \\
\hline & Facebook & -0.011 & 0.100 & -0.010 & -0.106 & 0.916 \\
\hline & Instagram & 0.492 & 0.117 & 0.411 & 4.203 & 0.000 \\
\hline
\end{tabular}




\section{a. Dependent Variable: penjualan}

Dari data Tabel 5. diatas dapat di artikan sebagai berikut

1. Nilai constanta adalah 2,309 artinya jika terjadi perubahan variabel pada iklan Facebook X1 dan iklan Instagram X2, (Nilai X1 dan X2 adalah 0 ) maka penjualan perumahan di Palembang sebesar 2.309

2. Nilai koefisien iklan Facebook sebesar - 0,011 artinya iklan Facebook (X1) tidak mengalami peningkatan apabila meningkat $1 \%$ atau 1 maka penjualan (Y) akan berpengaruh.

3. Nilai koefisien iklan Instagram sebesar $+0,492$ artinya iklan Instagram (X2) mengalami peningkatan. apabila meningkat $1 \%$ atau 1 maka penjualan $(\mathrm{Y})$ mengalami peningkatan

\subsection{Pembahasan}

Dilihat pada tabel model summary koefisien korelasi dapat disimpulkan bahwa hubungan kedua variabel terhadap penjualan tergolong sedang.Untuk nilai $\mathrm{R}$ Square atau koefisien determinasi (KD) yang menunjukkan bahwa variabel bebas Facebook dan instagram memiliki pengaruh kontribusi sebesar 16,6 \% terhadap variabel $\mathrm{Y}$ dan 83,4 \% lainnya dipengaruhi oleh faktor-faktor lain diluar variabel bebas

Dilihat dari tabel anova

bahwa variabel terikat memiliki nilai koefisien regresi $F_{\text {hitung }}$ lebih besar dari pada $F_{\text {tabel }}$. Dapat disimpulkan bahwa (Instagram, facebook) berpengaruh secara bersama-sama dan signifikan terhadap variabel dependen (Penjualan)

Dilihat dari tabel coefficients dapat di simpulkan bawah kedua media sosial facebook dan instagram sebesar 2.309 jika dibandikan kedua media sosial ini maka iklan instagramlah yang lebih berpegaruh terhadap penjualan.

\section{Kesimpulan}

Berdasarkan dari hasi pembahasan diatas peneliti dapat menarik kesimpulan dari penelitian ini yang bertujuan untuk mengetahui dampak media iklan Facebook dan instagram terperhadap hasil penjualan perumahan di Palembang dan hasil yang didapat sebagai berikut :

1. Untuk hasil dari pengujian menyatakan bahwa tidak berpengaruh yang signifikan terhadap hasil penjualan menggunakan media iklan Facebook

2. Untuk hasil dari pengujian Dampak media iklan Instagram terhadap hasil penjualan perumahan hasil didapat berpegaruh positif menggunakan media iklan Instagram.

3. Untuk hasil pengujian dengan menggunakan kedua media iklan facebook dan insatgram menunjukkan bahwa berpengaruh secara bersama-sama dan signifikan terhadap penjualan.

Adapun saran dari penelitian ini sebagai berikut.

1. Melihat dari data tabulasi (Iklan Facebook) ada beberapa pertanyaan yang nilai rataratanya kecil. Yang disebabkan dalam melakukan iklan di media sosial Facebook kurang efektif dalam penjualanya. seperti iklan yang di sampaikan kurang lengkap, tidak sesuai kenyataan dan kurang jelas. adapun saran dari peneliti untuk dapat membuat iklan lebih efektif dalam penggunaan, yaitu dengan cara membuat iklan itu tersendiri lebih lengkap dan jelas dalam penyampaianya dan juga menampikan gambar - gambar yang sesuai kenyataan, atau reil bagunan yang sudah jadi/nyata. 
2. Dari data tabulasi (iklan Instagram) sudah efektif dalam melakukan iklan di media sosial. Sudah dilakukan uji F menujukan agka yang positif, saran peneliti yaitu lebih meningkatkan beriklan di instagram membuat pembaruan - pembaruan sehingga masyarakat lebih meyakinkan diri untuk membeli perumahan dan tentunya lebih meningkatkan penjualan.

3. Untuk Penjualan, setelah di teliti yang membuat masyarakat lebih tertarik membeli. iyalah dengan cara memberikan bonus dalam setiap pembeli pembelian 1 unit perumahan. Saran dari peneliti selalu memberikan bonus setiap pembelian.

\section{Referensi}

Adhi Suryo, L., Suddin, A., \& Widajanti, E. (2019). Pengaruh Harga, Iklan, Citra Merk, Dan Pelayanan Purna Jual Terhadap Keputusan Pembelian Mobil Wuling Di Wilayah Surakarta. Jurnal Manajemen Sumber Daya Manusia, 13(2), 395-404.

Hari Wibisono, Y. (2012). Faktor-faktor yang mempengaruhi perilaku pembelian dengan perilaku niat sebagai variabel intervening pada situs kaskus.Surabaya: Universitas Katolik Widya Mandala. Kajian Ilmiah Mahasiswa Manajemen, 1, 2012.

Hurriyati, R., \& Gunarto, M., 2019, Metode Statistika Bisnis Untuk Bidang Ilmu Manajemen dengan Aplikasi Program SPSS, Rafika Aditama, Bandung.

Indrawati, K., Nyoman Sudiarta, I., \& Wayan Suardana, I. (2017). Efektivitas Iklan Melalui Media Sosial Facebook Dan Instagram Sebagai Salah Satu Strategi Pemasaran Di Krisna Oleh-Oleh Khas Bali. Analisis Pariwisata.

Murad, S., \& Rafsanjani, A. (2016). Pengaruh Kreatifitas Iklan Terhadap Keputusan Pembelian Produk Smartfren Di Kota Banda Aceh (Studi pada Pelanggan Smartfren di Kota Banda Aceh) SURYANI. 51(1), 51.

Musfar, T. (2020). Manajemen Pemasaran. Cv.Media Sains Indonesia.

Puntoadi, D. (2011). menciptakan penjualan melalui sosial media.

Roma Doni, F. (2017). Perilaku Penggunaan Smartphone Pada Kalangan Remaja. Journal Speed Sentra Penelitian Engineering Dan Edukasi, 9(2), 16-23.

Septi Haryani, D. (2019). Pengaruh Periklanan Dan Promosi Penjualan Terhadap Keputusan Pembelian Pada Perumahan Griya Puspandari Asri Tanjungpinang. Jurnal Dimensi, 8(1), 54-70. https://doi.org/10.33373/dms.v8i1.1827

Setiawan Sumana Putra, S., \& Wulandari, A. (2018). Efektivitas Iklan Motor Vespa Melalui Media Sosial Instagram Dengan Menggunakan Metode Epic (Studi pada Konsumen Vespa di Kabupaten Bandung Selatan Tahun 2018). In e-Proceeding of Applied Science (Vol. 5, Issue 1).

Sugiyono. (2016). Metode Penelitian Kuantitatif, Kualitatif dan R\&D. PT. Alfabet.

Tasliman, M., \& Tresna Suryawibawa, D. (2019). Analisis Pemanfaatan Facebook. Prosiding, 940-945.

Zarrella, D. (2010). The Sosial Marketing Book. Reilly media, Inc. 
Vol. 3, No. 1, Januari 2022

\section{Copyrights}

Copyright for this article is retained by the author(s), with first publication rights granted to the journal.

This is an open-access article distributed under the terms and conditions of the Creative Commons Attribution license (http://creativecommons.org/licenses/by/4.0/) 